\title{
Large Recurrent Radicular Cyst in Maxillary Sinus: A Case Report
}

\author{
Gran Quiste Radicular Recurrente en Seno Maxilar: Reporte de Caso
}

Ignacio Velasco'; Soheil Vahdani²; Natalia Nuñez ${ }^{3}$ \& Héctor Ramos ${ }^{4}$

VELASCO, I.; VAHDANI, S.; NUÑEZ, N. \& RAMOS, H. Large recurrent radicular cyst in maxillary sinus: A case report. Int. J. Odontostomat., 11(1):101-105, 2017.

ABSTRACT: Radicular cyst is the most common inflammatory jaw cystic lesion that occurs in necrotic teeth. They account for more than $50 \%$ of all odontogenic cysts. Radicular cysts cause slowly progressive painless swelling and there are no symptoms until they become large. Enucleating the cyst with endodontic therapy of the affected tooth is recommended as the primary treatment. Here we describe a patient with a large recurrent radicular cyst with maxillary sinus involvement who underwent a midfacial degloving approach for complete enucleation. In conclusion, radicular cyst should be considered in the differential diagnosis of large maxillary sinus lesions and never be discarded until histopathology is available.

KEY WORDS: radicular cyst, maxillary sinus, odontogenic cyst.

\section{INTRODUCTION}

Radicular cyst $(\mathrm{RC})$ is also known as periapical cysts, dental cysts, or apical periodontal cyst. RC is the most common inflammatory odontogenic cystic lesion of the maxillary bones that accounts for more than 50 $\%$ of all the odontogenic cysts (Nair et al., 2008). The incidence of RC is greater in the third to sixth decades and shows a slight male predominance (Shear \& Speight et al., 2007). RC affects teeth with infected and necrotic pulp. These cysts occur as the direct sequelae of chronic apical periodontitis (Nair et al.)

Most radicular cysts develop slowly and do not become very large. Patients do not experience pain unless acute inflammatory exacerbation is present, and the lesions are often detected only during routine radiographic examination, which is noted as a round or oval, unilocular, well-circumscribed radiolucency attached to the root of a tooth (Johann et al., 2006). If the cyst does become large, symptoms such as swelling, mild sensitivity, tooth mobility and displacement may be observed. The affected tooth is nonresponsive to thermal and electrical pulp tests (Lin et al., 2009). RC can be treated with conservative endodontic therapy in small lesions, or combined with biopsy, marsupialization and enucleation (Martin, 2007). Cysts of inflammatory origin do not recur after appropriate management (Shear \& Speight et al.).

Radicular cysts of large size are uncommon, but may present a diagnostic challenge. The objective of our case report is to describe the presentation and management of an unusual recurrent large $R C$ in the maxillary sinus.

\section{CASE REPORT}

A 57-year-old man was referred to the Oral and Maxillofacial Surgery clinic at the School of Dental Medicine of the University of Puerto Rico (San Juan, $\mathrm{PR}$ ) with the chief complaint of right facial inflammation which had continuously evolved over the preceding 12 months. The patient had a history of surgical

\footnotetext{
${ }^{1}$ Chief Resident. Department of Oral and Maxillofacial Surgery, University of Puerto Rico. San Juan, Puerto Rico.

${ }^{2}$ Resident. Department of Oral and Maxillofacial Surgery, University of Puerto Rico. San Juan, Puerto Rico.

${ }^{3}$ Resident. Department of Advanced Education in General Dentistry, University of Puerto Rico. San Juan, Puerto Rico.

${ }^{4}$ Professor. Department of Oral and Maxillofacial Surgery, University of Puerto Rico. San Juan, Puerto Rico.
} 
treatment of a right maxillary cyst 37 years ago without past medical record available. At that time patient refers that root canal treatments were performed in the involved teeth. The patient had remained asymptomatic until one year ago when presented with intermittent dental pain in the right anterior maxilla associated with a purulent gingival discharge. The patient denied suffering fever, facial paresthesia, nasal bleeding, or weight loss.

Extraoral examination showed painless swelling limited at the right cheek region. No paresthesia was registered and no lymphadenopathy was found. Intraoral examination revealed soft and fluctuant well-defined swelling extending from the right central incisor to the second bicuspid. All the right maxillary teeth presented class III mobility. The overlying mucosa was non-ulcerated and unchanged in color. There was no evidence of oroantral communication, and the palatal mucosa was intact.

Panoramic radiograph and maxillofacial computed tomography (CT) revealed a large welldefined unilocular cystic lesion measuring $4.6 \times 3.4 \times$ $3.3 \mathrm{~cm}$ in dimension occupying most of right maxillary sinus and part of the lateral nasal cavity with erosion of the anterior wall of the maxilla, associated with the roots of the anterior teeth (Figs. 1 and 2). On the basis of the clinical and radiographic findings, the differential diagnosis of RC, ameloblastoma and keratocystic odontogenic tumor (KOT) were made.

Under local anesthesia the lesion was first aspirated to rule out a vascular lesion then incisional biopsy and marsupialization with decompression using a silicone tube was performed. Histopathologic examination revealed nonkeratinizing stratified squamous epithelium and fibrous connective tissue confirming the diagnosis of RC (Fig. 3).

After three months, radiographic examination with cone beam tomography revealed small reduction in the lesion and enucleation of the cyst was indicated. Under general anesthesia, the patient underwent cyst enucleation through a midfacial degloving approach (Fig. 4). The lesion membrane was removed completely and right maxillary teeth were extracted due to poor periodontal prognosis, the mucosa was sutured in two layers with the interposition of the right buccal fat pad. Final histopathologic examination confirmed the initial diagnosis. The patient's postoperative course was unremarkable. Follow-up at 3-6-12 months revealed no evidence of disease, and the patient was also free from symptoms.

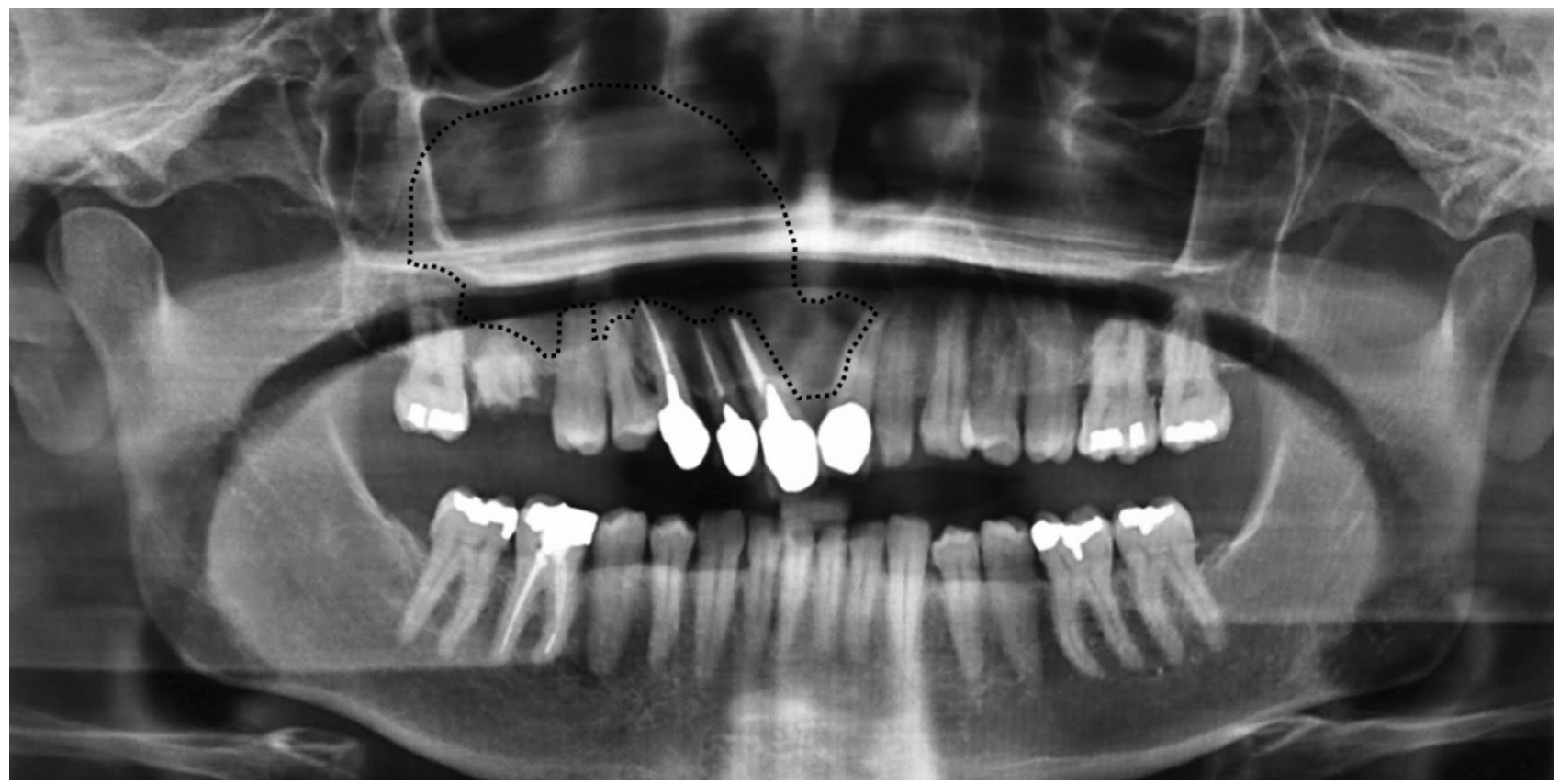

Fig. 1. Panoramic radiograph revealed large right maxillary sinus unilocular radiolucent lesion (dotted line). 


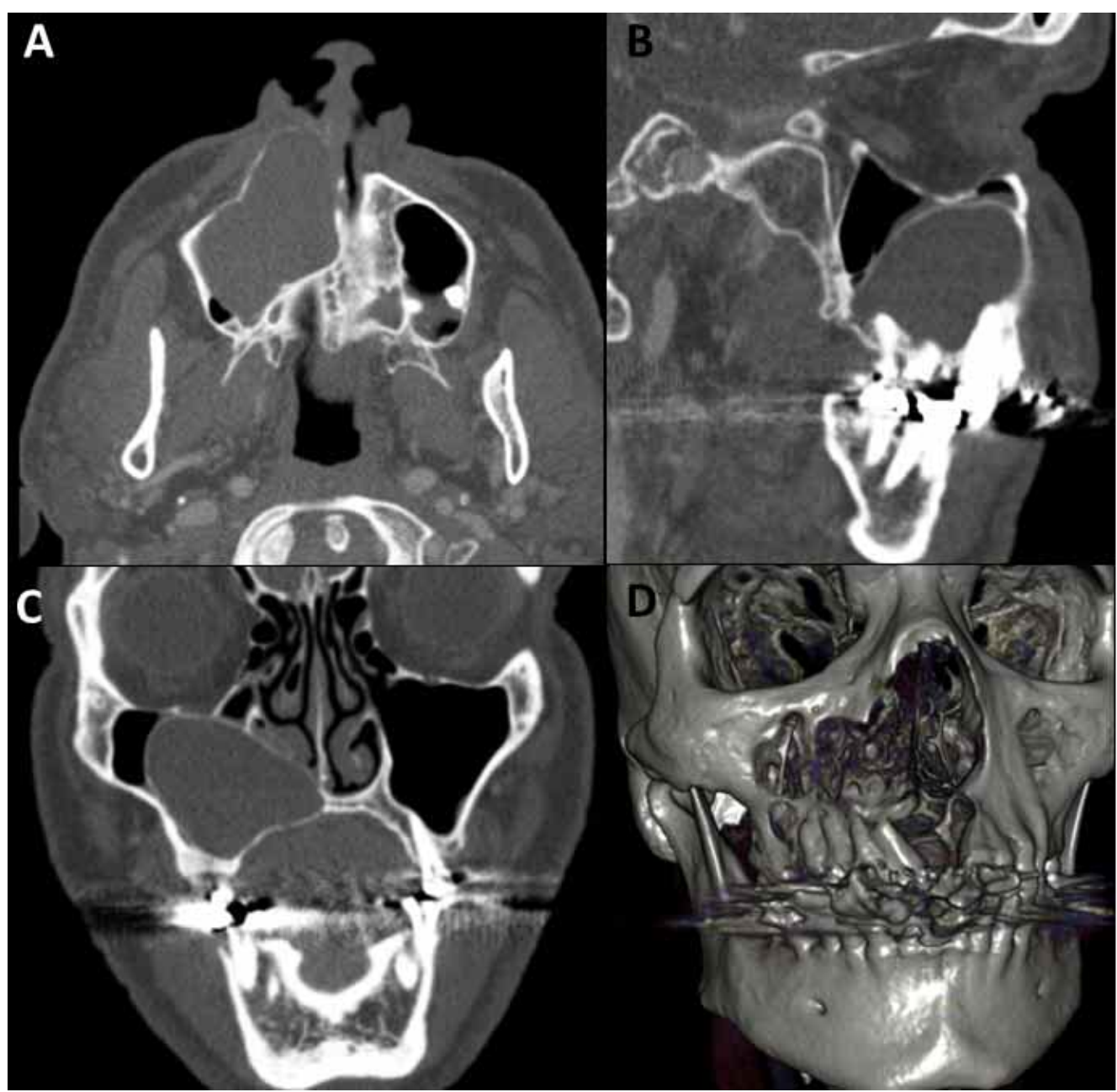

Fig. 2. CT scan that showed hypodense lesion in right maxillary sinus with involvement of lateral nasal wall and erosion of anterior maxilla. A- axial view, B- sagittal view, C- coronal view, D- 3D reconstruction.

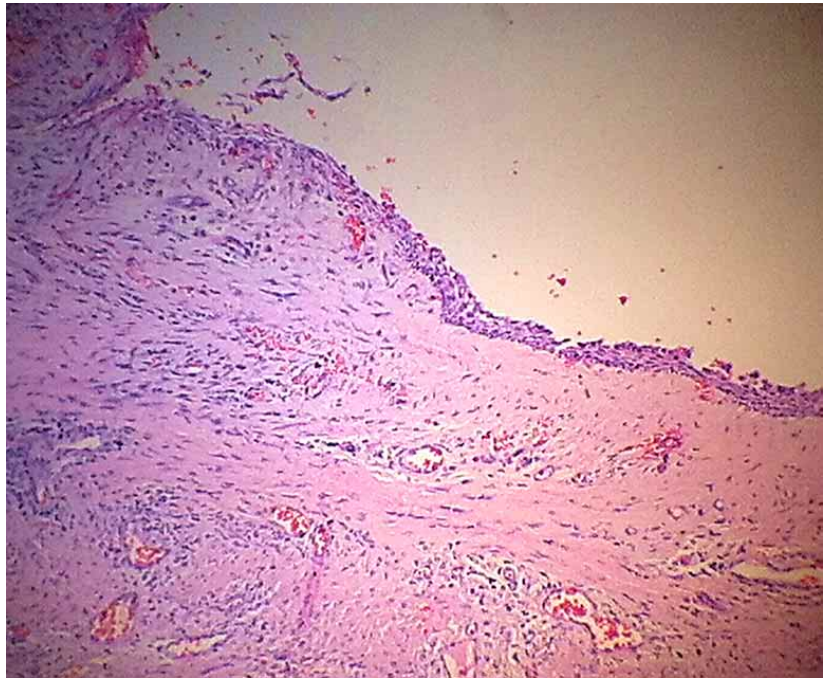

Fig. 3. Incisional biopsy histopathology, hematoxylin-eosin stain, 60X augmentation.

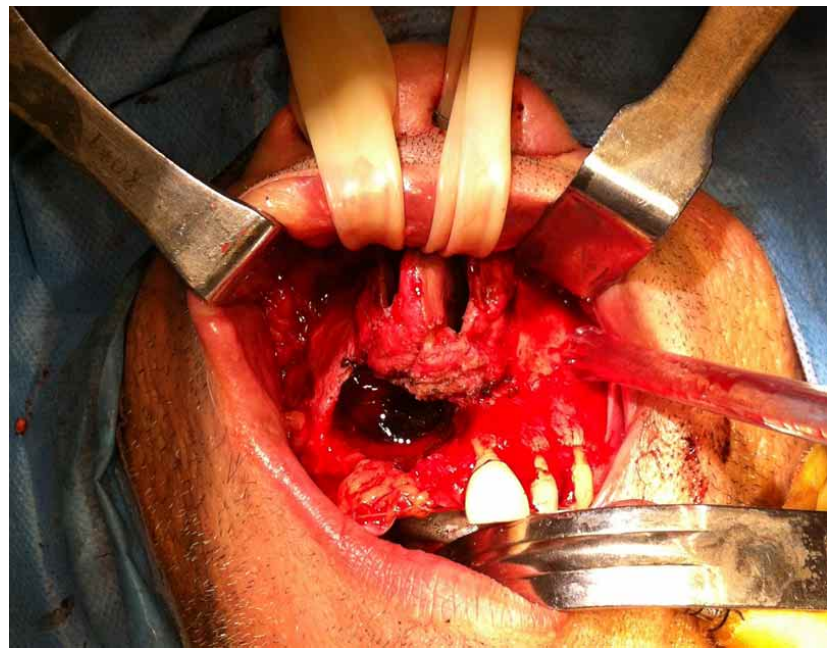

Fig. 4. Midfacial degloving approach. 


\section{DISCUSSION}

A wide variety of cysts and neoplasms may occur in the maxillary region, and their identification can be difficult. The most common of these are odontogenic cysts with $52 \%$ of jaw cystic lesions and it presents $60 \%$ times more in maxilla than in mandible (Shear \& Speight). RC are thought to arise from epithelial cell rests of Malassez in the periodontal ligament, and they are believed to proliferate as a result of periapical inflammation caused by infection of the root canal system (Shear \& Speight).

In radiologic diagnosis it appears as an oval or rounded radiolucency, with a well-defined cortical border, however, enormous RC seldom appears, and when they get to certain sizes, they are diagnosed as other pathologic lesions such as KOT or dentigerous cyst (Dimitroulis \& Curtin, 1998; Scholl et al., 1999). That's why differential diagnosis of the RC should include dentigerous cyst, residual cyst, lateral periodontal cyst, paradental cyst, glandular odontogenic cyst, incisive canal cyst, Stafne bone defect, traumatic bone cyst, and odontogenic tumors (ameloblastoma, KOT).

$\mathrm{RC}$ cause slowly progressive painless swelling. There are no symptoms until they become large (Sagit et al., 2011). If infected, the swelling becomes painful and may rapidly increase in size, because chronic inflammation is considered the main cause of the cyst growing (Shear \& Speight). In our case the RC filled completely the maxillary sinus and destroyed the anterior wall of the maxillary sinus, mimicking a more aggressive lesion.

The treatment of the maxillary cysts must be individualized according to the clinic characteristics (Shear \& Speight). The management of large cystic lesions has been the subject of prolonged debate, but surgical treatment may be the preferred approach to treating a large RC (Torres-Lagares et al., 2011). The usual surgical treatments for RC include total enucleation of small lesions, marsupialization for decompression of larger cysts or a combination of these techniques. Should surgical intervention become necessary, the clinician must decide whether to raise a flap and completely enucleate the lesion or to try "decompression" first (Torres-Lagares et al.). If marsupialization with decompression is attempted first, the size of the lesion will be reduced, which will make it less difficult to remove, with less risk of damage to the associated teeth and vital structures (Martin). Consequently, in our case, due to its size and nonresponding decompression a more aggressive approach was chosen to remove it completely. We used the midfacial degloving approach for a complete exposure of the middle third of the face, this access offers an excellent cosmetic result with no external scarring (Kitagawa et al., 2003).

Total removal of the cystic membrane is essential to prevent the recurrence of the lesion, which was the probable cause of relapse in our case, also it allows a complete histopathological examination. In conclusion, $\mathrm{RC}$ should be considered in the differential diagnosis of large maxillary sinus lesions and never be discarded until histopathology is available.

VELASCO, I.; VAHDANI, S.; NUÑEZ, N. \& RAMOS, H. Gran quiste radicular recurrente en seno maxilar: Reporte de caso. Int. J. Odontostomat., 11(1):101-105, 2017.

RESUMEN: El quiste radicular es la lesión inflamatoria quística más común que ocurre en los dientes necróticos. Su presentación abarca más del $50 \%$ de los quistes odontogénicos. Los quistes radiculares se presentan como una inflamación indolora de crecimiento lento y progresivo y se hacen sintomáticas una vez que alcanzan un gran tamaño. El tratamiento primario recomendado para este quiste es la enucleación junto al tratamiento endodóntico de los dientes afectados. Presentamos un reporte de caso de un paciente que presentaba un gran quiste radicular recurrente con envolvimiento de todo el seno maxilar y que fue tratado con un acceso intraoral extendido para lograr la completa enucleación de la lesión. En conclusión, el quiste radicular debe ser siempre considerado en el diagnóstico diferencial de lesiones de gran tamaño que involucren el seno maxilar y nunca ser descartado hasta tener el resultado de histopatología.

PALABRAS CLAVE: quiste radicular, seno maxilar, quiste odontogénico

\section{REFERENCES}

Dimitroulis, G. \& Curtin, J. Massive residual dental cyst: case report. Aust. Dent. J., 43(4):234-7, 1998.

Johann, A. C.; Gomes, C. de O. \& Mesquita, R. A. Radicular cyst: a case report treated with conservative therapy. J. Clin. Pediatr. Dent., 31(1):66-7, 2006.

Kitagawa, Y.; Baur, D.; King, S. \& Helman, J. I. The role of midfacial degloving approach for maxillary cysts and tumors. J. Oral Maxillofac. Surg., 61(12):1418-22, 2003.

Lin, L. M.; Ricucci, D.; Lin, J. \& Rosenberg, P. A. Nonsurgical root 
canal therapy of large cyst-like inflammatory periapical lesions and inflammatory apical cysts. J. Endod., 35(5):607-15, 2009.

Martin, S. A. Conventional endodontic therapy of upper central incisor combined with cyst decompression: a case report. J. Endod., 33(6):753-7, 2007.

Nair, P. N.; Sundqvist, G. \& Sjögren, U. Experimental evidence supports the abscess theory of development of radicular cysts. Oral Surg. Oral Med. Oral Pathol. Oral Radiol. Endod., 106(2):294-303, 2008.

Sagit, M.; Guler, S.; Tasdemir, A. \& Akf Somdas, M. Large radicular cyst in the maxillary sinus. J. Craniofac. Surg., 22(6):e64-5, 2011.

Scholl, R. J.; Kellett, H. M.; Neumann, D. P. \& Lurie, A. G. Cysts and cystic lesions of the mandible: clinical and radiologichistopathologic review. Radiographics, 19(5):1107-24, 1999.

Shear, M. \& Speight, P. Cysts of the Oral and Maxillofacial Regions. Oxford, Wiley-Blackwell, 2007. pp.123-42.

Torres-Lagares, D.; Segura-Egea, J. J.; Rodríguez-Caballero, A.; Llamas-Carreras, J. M. \& Gutiérrez-Pérez, J. L. Treatment of a large maxillary cyst with marsupialization, decompression, surgical endodontic therapy and enucleation. J. Can. Dent. Assoc., 77:b87, 2011
Correspondence to:

Ignacio A. Velasco

Department of Oral and Maxillofacial Surgery

University of Puerto Rico

San Juan

PUERTO RICO

E-mail: ignacio.velasco@upr.edu

Recibido: 26-08-2016

Aceptado: 30-12-2016 